\title{
Emerging and re-emerging viral infections in Europe
}

\author{
Agostino Pugliese ${ }^{1 *}$, Tiziana Beltramo ${ }^{1}$ and Donato Torre ${ }^{2}$ \\ ${ }^{1}$ Department of Medical and Surgical Sciences, Section of Clinical Microbiology of Turin University, "Amedeo di Savoia”" \\ Hospital, Turin, Italy \\ ${ }^{2}$ Infectious Diseases Section, General Hospital, Cittiglio (Varese), Italy
}

\begin{abstract}
Emerging viral infections are becoming a serious problem in Europe in the recent years. This is particularly true for severe acute respiratory syndrome (SARS), West Nile virus (WNV) disease, Toscana virus (TOSV) disease, and potentially for avian influenza virus (H5N1). In contrast, emergence or re-emergence of severe viral infections, including tick borne encephalitis virus, and viral haemorrhagic fever caused by Hantavirus and dengue virus have been frequently reported in several European countries. Laboratory diagnosis of these viral infections based on viral isolation or detection by immune electron microscopy, immunoassay and polymerase chain reaction (PCR) has dramatically improved in the recent years, and SARS represents a good example of a diagnostic approach to emerging viral infections. Finally, old and new promising agents are in the pipeline of pharmaceutical companies to treat emerging viral infections. However only prevention based on large epidemiological studies, and research and development of new vaccines may be able to control and eventually eradicate these deadly viral infections. Copyright (C) 2006 John Wiley \& Sons, Ltd.
\end{abstract}

\section{INTRODUCTION}

Emerging or re-emerging viral infections represent an important problem of public health in the recent years. This phenomenon in part is due either to infective agents' evolution, or to globalisation, and habitat modification. ${ }^{1}$ In particular, emergent infective viruses can originate by variation of previously present agents (genetic mutations and/or recombinations) or as a consequence of animal viruses adapting to human hosts. Also, the introduction of new infective agents in a determined area can be significant. ${ }^{2,3}$ Instead, reemergent infections can originate by reactivation of quiescent reservoirs or as a consequence of the reappearance of previously circulating viruses that have spread to other areas. In addition, changes in the behaviour of human population, and in their habitat, as well as migration, deforestation, agricultural evolution or involution, and climate modification may also contribute to the onset and diffusion of new viral

* Correspondence to: A. Pugliese, Department of Medical \& Surgical Sciences, Section of Clinical Microbiology, University of Turin, C/o 'Amedeo de Savoia' Hospital, Corso Svizzera 164, I-10149, Torino, Italy. Tel: +39 011439 3865. Fax: +39 0114393882 .

E-mail: pugliese@dealer.it infections. ${ }^{4}$ Finally, the possibility of covering long distances in a brief time can permit the rapid introduction of infective agents in areas previously unaffected. This may occur directly from person to person or indirectly through arthropod vectors or other carrier animals, and sometimes by means of goods transport ${ }^{4}$ (Table 1).

Historically, several severe epidemics, including plague, originated from southeast Asia. ${ }^{5}$ Recently this area has produced two types of serious viral-emerging infections: Severe Acute Respiratory Syndrome (SARS), caused by very virulent strains of new Coronaviruses, and aviary influenza (especially produced by the strain $\mathrm{A} / \mathrm{H} 5 \mathrm{~N} 1){ }^{3,6,7}$ Other emergent viruses, such as the West Nile one, originated from Africa. 8

Rabies is present in many depressed areas but is reemerging in North America and in Europe. Especially, in the latter continent, Lyssavirus infection of bats represents an effective zoonosis that can also affect humans. ${ }^{9}$

In the occidental world increase in travel has promoted the importation of some exotic infections such as dengue, hepatitis E, West Nile, and haemorrhagic fevers that are diffused in various areas of Africa and Asia. ${ }^{10,11}$ Also, there has been a recent diffusion 
of Tick-borne encephalitis virus in south European countries, coming from Euro-Asiatic forests, and in part from the Danube basin. These are issues of serious concern, ${ }^{12}$ together with the spread of emergent neurotropic Toscana virus (TOSV) in Mediterranean areas. ${ }^{13}$

Preventive strategies for emerging or re-emerging infections are hardly studied by infectivologists and epidemiologists. For prevention and control of these infections, vaccine strategies, chemoprophylaxis (rarely for viral agents), and actions against the vectors have been used, but these measures have sometimes proved to be poorly effective, especially in the absence of a deep control of healthy population. ${ }^{4}$ However, an international collaboration on infectious diseases control may often obtain effective results. An example of this action is the success attained, up to now, in the control of the emergent epidemic of SARS. ${ }^{14}$

\section{RESPIRATORY INFECTIONS}

During the spring of 2003 the onset of an unknown respiratory epidemic was noticed in southeast China which previously seemed to be due to emerging parainfluenza viruses but was subsequently demonstrated to be caused by new Coronavirus types (two types and several strains). ${ }^{15}$ Because of severe respiratory involvement in this syndrome (bronchopneumonia and bronchiolitis) ${ }^{16}$ which can also produce enteric manifestations and hepatic dysfunctions, the virus was named SARS. ${ }^{17}$ Indeed, the Italian physician Dr Carlo Urbani had announced the new emergent epidemic in February 2003, but unfortunately he died from this infection. During a medical Congress in Hong Kong where physicians from different parts of the world had gathered, some of the participants were infected by the SARS coronavirus and then the epidemic spread to various parts of the world, especially in Toronto (Canada). ${ }^{18,19}$ By the end of June 2003, when the epidemic seemed to recede, the number of cases announced in the world were more than 8000 , with a total mortality index of $10-15 \%$. However, the mortality reached $50 \%$ in people aged over 65 years. ${ }^{20}$

Transmission of the SARS virus is from person-toperson, but it also propagated indirectly through excreta and stagnant water. Moreover, some animals, such as civet cats, ferrets, bandits eye, badgers, and perhaps bats, may constitute reservoirs of the infection. ${ }^{21-23}$

The incubation period is about $2-7$ days, ${ }^{20}$ but at present, the percentage of possible asymtomatic or paucisymptomatic infections is unknown, as is also the amount of clinical manifestations not followed by lung involvement. Additionally, the percentage of patients evolving in irreversible fibrosis is also unknown. ${ }^{24}$ For critical patients with acute respiratory distress, mechanical ventilation is required. ${ }^{19}$ Several antiviral therapies have been proposed, but at present only treatment with interferon ${ }^{25}$ or with hyperimmune globulins seems to be effective. ${ }^{26}$ Use of anti-sense oligonucleotides does not appear to be useful. However, a suggestive therapeutic perspective is that of blocking the renin-angiotensin pathway. In fact, angiotensin-converting enzyme 2 (ACE2) seems to be a possible receptor of the causative virus. ${ }^{27}$ Laboratory diagnosis of SARS can be made using direct methods such as isolation and polymerase chain reaction (PCR), and indirect ones such as neutralisation, ELISA, indirect immunofluorescence and immunochromatographic tests that may also be employed for IgM demonstration. ${ }^{28-30}$

As previously noted, fortunately, world collaboration in respiratory infection control has, at least up to now, averted the hazard-one SARS.

In Europe, only 20 suspected cases have been found, and half of them were really infected. In particular, five were found in France (two really affected) ${ }^{31}$ and three in Germany (two developed SARS). ${ }^{32}$ In Italy, four imported probable cases were identified. ${ }^{33}$ In consequence, SARS viral infection constitutes a threat in Europe as well.

Table 2 summarises clinical manifestations of the main emergent and re-emergent viral respiratory infections.

At present, there is more concern regarding the spread of avian influenza in humans. ${ }^{34-35}$ Influenza viruses have caused serious epidemics and pandemics in humans (involvement of the whole world), beginning from times when viral etiology was

Table 1. Factors contributing to emergent and re-emergent viral infections in Europe

\footnotetext{
- Poverty

- Global climate change

- Changes in human demographics and behavior

- Environmental changes, including heavy rains followed by flood, and rehabilitation of wetlands (increased incidence of mosquito-vector population)

- Tourism and business travels

- Global trade in wildlife

- Adaptation of animal viruses to human host

- Introduction of exotic agents by human and animal migration

- Animal smuggling (especially of birds)

- The breakdown of public health measures
} 
Table 2. Clinical manifestations of main emergent and re-emergent viral respiratory infections in Europe

\begin{tabular}{lll}
\hline Type of infection & Etiologic agent & Clinical manifestations \\
\hline SARS & Coronavirus & $\begin{array}{l}\text { Pneumonia, bronchiolitis, adult respiratory distress } \\
\text { syndrome (ARDS) } \\
\text { Influenza-like illness, pneumonia, ARDS, conjunctivitis, } \\
\text { gastrointestinal disorders, hepatic and renal impairment }\end{array}$ \\
$\begin{array}{l}\text { Avian influenza } \\
\text { prevalently H5N1 }\end{array}$ & Orthomyxovirus \\
$\begin{array}{l}\text { and H7N7) } \\
\begin{array}{l}\text { Metapneumovirus } \\
\text { and Enterovirus } 71\end{array}\end{array}$ & $\begin{array}{l}\text { Paramyxovirus } \\
\text { Adenovirus } \\
\text { (especially type 4) }\end{array}$ & Picornavirus \\
\hline
\end{tabular}

unknown. The most serious was the pandemic of 1918 (type $\mathrm{A} / \mathrm{H} 1 \mathrm{~N} 1$ ) that caused more deaths than those produced by the First World War, and it re-emerged from Russia during an epidemic in $1977 .{ }^{36}$ More recently, influenza pandemics of Asian origin, occurred, respectively, in 1957 (A/H2N2) and 1968 (A/H3N2), and were also notable for their spread and severity. ${ }^{36,37}$ Moreover, some avian type A influenza strains are considered to be emergent viruses with serious impact on human health, but fortunately its direct transmission to man, and especially from person to person, represents an uncommon possibility. ${ }^{38,39}$ However, recently a 11-year-old Thai girl, infected with H5N1 avian virus, seems to have directly transmitted the infection to her mother, who died together with the daughter, and to an aunt who survived. ${ }^{40}$ Also during 2004, 44 persons living in southeast Asia were infected by $\mathrm{A} / \mathrm{H} 5 \mathrm{~N} 1$ poultry virus, of whom 32 died (mortality rate of about $73 \%) .{ }^{40} \mathrm{~A}$ higher number of cases was reported by the World Health Organization, during the winter-spring 2005 period, and December 2005-February 2006 period, when $\mathrm{H} 5 \mathrm{~N} 1$ also reached some regions of Turkey (on February 14, 2006, laboratory confirmed cumulative human cases were 169 , with a mean mortality rate of about $54 \%$ ). This virus spread during the second half of 1990s in Asia, and in 1997 diffused into Hong Kong affecting 18 individuals of whom 6 died (mortality rate of $33 \%$ ). ${ }^{41}$ As previously noted, the original $\mathrm{A} / \mathrm{H} 5 \mathrm{~N} 1$ strain and similar strains subsequently spread in Asia, during the winter of 2003-2004, especially in Vietnam, Thailand, and China with a higher number of human deaths (over $70 \%$ ). In fact, the H5N1 avian influenza virus that originated in ducks, progressively showed increase of pathogenicity for animals and a possible greater hazard for men. ${ }^{41,42}$ Recently in Thailand, strains with a fixed mutation in M2 causing amantadine resistance were found. ${ }^{42}$ Moreover, during the winter of 20042005 an avian epidemic caused by A/H5N1 spread particularly in Vietnam, Thailand, and Cambodia, and during the winter of 2005-2006 it spread westwards and reached east Europe. Beginning from the winter of 2003 , the virus has already killed over 90 people and caused the death of hundreds of millions of birds. Another emerging influenza virus strain of concern is A/H9N2 noticed in North America and in Asia is carried by turkeys and migratory ducks, and in Korea by chickens. This virus may easily combine with H5N1 virus and produce new dangerous strains. ${ }^{43}$ Besides $\mathrm{A} / \mathrm{H} 7 \mathrm{~N} 3$, another emergent chicken virus had been isolated in British Columbian (Canadian) poultry farms. ${ }^{44}$ This virus spread in Italy also. During winterspring 2003 strain H7N7 caused a poultry epidemic in the Netherlands that also affected several farmers and members of their family, but generally with a nonsevere illness (about 450 persons). Often, conjunctivitis was the only clinical manifestation. ${ }^{45}$ Oseltamivir and a specific vaccine employed together as appropriate veterinary interventions stopped the epidemic.

Table 3 reports the most important episodes of avian viruses spread in European countries.

As previously mentioned, avian influenza viruses could transfer cross-species to reach humans, however, with a low probability of direct transfer. Moreover, there is a possibility of human infection by these strains through an intermediate passage through large mammalian species, such as pigs, or a recombination of avian strains with human influenza viruses, circulating at the same time. ${ }^{39,52}$ Moreover, in the case of avian influenza, it is important to differentiate the strains into low pathogenicity (LP) and high pathogenicity (HP). ${ }^{53}$ In addition, H5N1 genotype $\mathrm{Z}$ that originated in southeast China and spread to some parts of the world and which is a HP strain, showed emergence of resistance to 
Table 3. Diffusion of avian influenza strains in Europe

\begin{tabular}{lccc}
\hline Author (reference) & Influenza strain & Infection period & Geographic area \\
\hline Okazaki et al., $2000^{46}$ & $\mathrm{~A} / \mathrm{H} 5 \mathrm{N1} \mathbf{H}^{*}$ & $1996-1998$ & Siberia \\
Van Borm et al., $2005^{47}$ & $\mathrm{~A} / \mathrm{H} 5 \mathrm{~N} 1$ & 2005 & Belgium \\
Timen et al., $2005^{48}$ & $\mathrm{~A} / \mathrm{H} 5 \mathrm{~N} 1$ & 2005 & Turkey, Romania, \\
& & & and Russia \\
Alexander, $2003^{49}$ & $\mathrm{~A} / \mathrm{H} 5 \mathrm{~N} 2$ & 1997 & Northeastern Italy \\
Alexander, $2003^{49}$ & $\mathrm{~A} / \mathrm{H} 7 \mathrm{~N} 1$ & $1999-2000$ & Northeastern Italy \\
Marangon et al., $2004^{50}$ & $\mathrm{~A} / \mathrm{H} 7 \mathrm{~N} 1$ & $2000-2001$ & Italy \\
Marangon et al. $2004^{50}$ & $\mathrm{~A} / \mathrm{H} 7 \mathrm{~N} 3$ & 2002 & Italy \\
Fouchier et al., $2004^{51}$ & $\mathrm{~A} / \mathrm{H} 7 \mathrm{~N} 7$ & 2003 & The Netherlands \\
Alexander, $2003^{49}$ & $\mathrm{~A} / \mathrm{H} 9 \mathrm{~N} 2$ & $1997-2002$ & Germany, Ireland, Italy, \\
& & & and Hungary \\
\hline
\end{tabular}

*During February 2006 H5N1 spread in south Italy and in Croatia.

adamantanes, and recently to oseltamivir also. Consequently, many studies are underway exploring the use of various vaccines in different countries. ${ }^{53}$

A brief incubation period of 1-3 days precedes respiratory manifestations of common influenza, and the illness duration in uncomplicated cases is about 5-7 days. ${ }^{54}$ However, bacterial complication of the lower respiratory tract, such as bronchitis and/or pneumonia, can seriously worsen the course of influenza, more frequently in debilitated and in old age persons. Viral pneumonia or neurologic and myocardial complications have been rarely reported. ${ }^{55-58}$ In humans, avian influenza that can take a longer incubation period (7 days or longer) is generally more serious with frequent cases of pneumonia and acute respiratory distress syndrome (ARDS). In addition, conjunctivitis, gastrointestinal manifestations, hepatic, and renal impairment are also likely to occur. ${ }^{59,60}$

Diagnosis of influenza can be made not only by viral isolation, PCR techniques, or serologic tests such as haemoagglutination-inhibition and ELISA, but also by employing new biosensor markers. ${ }^{41,61}$

A very high and efficient level of sanitary surveillance may prevent the unlucky event of influenza epidemics, especially the onset of dangerous emergent strains. In fact, population protection against influenza is possible with vaccine prophylaxis and with antiviral agents such as neuraminidase inhibitors and amantadine derivates. ${ }^{62}$ Antiviral drugs, especially the neuraminidase inhibitor, oseltamivir, may also be successfully employed for treatment of influenza, if the treatment is started early. ${ }^{63}$ However, pharmacologic resistance is also possible. ${ }^{64-66}$ Gerdil et al. ${ }^{67}$ noted that, each year, up to 500 million people are affected by influenza. Consequently, nearly 250 million vaccine doses are produced annually. ${ }^{67}$ In particular, during the 2004-2005 winter season, a trivalent vaccine was employed that contained $\mathrm{A} /$ Fujian/411/02 (H3N2), A/New Caledonia/20/99 (H1N1), and B/Shanghai/361/02 ${ }^{68}$ Moreover, experimental vaccines are being studied, using either attenuated or adenovirus vector modifications, for nasal and epicutaneous administration. ${ }^{69}$

Information about influenza epidemiology and prophylaxis can be provided by the Influenza Branch website of Division of Viral and Rickettsial Diseases-CDC, Atlanta, USA: http://www.cdc.gov/ incidod/diseases/flu/fluvirus.htm.

It is interesting to draw attention to the recently identified new human Metapneumovirus indicated as HMPV (Paramyxoviridae family, Pneumovirinae subfamily) that seriously affects children and persons over 65 years of age in Europe, North America, Australia, and Asia. ${ }^{70}$ This virus is similar to Respiratory Syncytial Virus (RSV) and is responsible for bronchiolitis and pneumonia. As previously noted, this emergent virus is particularly dangerous in infants, old people, immunocompromised patients and also in those affected by chronic respiratory diseases. $^{70}$

Finally, re-emergence of Enteroviruses, such as Coxsackie virus responsible for Bornholm disease, is also possible in Europe, as it occurred recently in Japan. ${ }^{71}$ Moreover, a similar phenomenon happened in the case of Coxsackievirus A16 and Enterovirus 71, responsible for "Hand, foot, and mouth disease" in children $^{72,73}$ and sometimes also for pulmonary infections. ${ }^{74-76} \mathrm{~A}$ new antiviral, Pleconaril, shows promise for enteroviruses infection. ${ }^{74}$ Similarly, adenoviruses can have re-emergent behaviour in parts of Europe, especially, type 4 re-emerged in USA. ${ }^{77}$ 
PCR diagnostic techniques, together with classic diagnostic tests, are at present successfully employed for Enteroviruses and Adenoviruses diagnosis. ${ }^{76,77}$

\section{HAEMORRHAGIC FEVERS}

Crimean-Congo haemorrhagic fever (CCHF) is a severe zoonosis endemic in Africa, in the middle east, and central and southwestern $\mathrm{Asia}^{78}$ and is reemergent in different European areas. This has occurred especially in the southern provinces of Russia, in Bulgaria, Greece, Kosovo, in some provinces of former Yugoslavia, in Albania, and also in some parts of Hungary, France, Portugal, ${ }^{78-80}$ and in Spain. ${ }^{81}$ The transmission of different strains of the etiologic viral agent (an arbovirus belonging to Nairovirus genus, Bunyaviridae family) is caused either by some Tick specie bites, especially belonging to Hyalomma genus, or by transcutaneous or respiratory routes, and perhaps by ingestion of infected raw milk. More rarely, the virus is transmitted by a nosocomial pathway. ${ }^{78} \mathrm{CCHF}$ was first recognised among farmers of the Crimean Peninsula in $1940{ }^{82}$ After an incubation period of 2-7 days, the infection is characterised by high fever, headache, dizziness, nausea, vomiting, diarrhoea, hepatic, and pulmonary involvement, neuropsychiatric, and cardiovascular disorders. Severe haemorrhagic manifestations, preceded by petecchial rash and ecchymosis, may cause death in about $30 \%$ of patients. ${ }^{82}$ At present molecular tests are used for the diagnosis (direct methods), and particularly useful is the employment of real-time reverse transcription-polymerase chain reaction (RT-PCR). ELISA tests are generally employed for serologic detection. ${ }^{78,82}$

Presently, there is no specific therapy for this viral infection although immunotherapy and ribavirin have been used with varying degrees of success. ${ }^{82}$ Support therapy is generally employed, and vaccines that are rarely available have also been proposed for prophylaxis. 78

Among tick-borne flaviviruses causing human haemorrhagic fevers, Omsk disease agent can be considered to be a Russian re-emergent virus. In fact, at the end of 1940 it was first isolated in a rural region of the Omsk district in Siberia. From that time, it has reappeared at different periods. In some small regions of Siberia, it was transmitted to humans by muskrats through tick bites of Dermacentor spp. ${ }^{78,83-85}$ Omsk haemorrhagic fever is similar in clinical manifestations to Kyasanur Forest disease and Saudi Arabia Alkhurma virus infection, all responsible for haemorrhagic fevers and sometimes for neurologic disorders as well. ${ }^{84}$
Biphasic behaviour of the infection may be present in $30-50 \%$ of the cases with appearance in the second stage of haemorrhagic manifestations. Fortunately, the prognosis is generally good; however, a mortality of $0.5-3 \%$ has been reported. ${ }^{78,86}$

Hantavirus genus (family Bunyaviridae) represents one of the main emergent, re-emergent viral groups responsible for haemorrhagic fever in Europe. ${ }^{87,88}$ The name is derived from the Han River basin where the infection was first identified in 1978. At present, different serotypes, grouped in Hantavirus genus, have been described in Asia, America, and Europe, having Arvicoline rodents as reservoir that can transmit the infection to humans through their excretions. ${ }^{89}$ These viruses spread worldwide and are responsible for fever with renal and/or pulmonary syndromes. ${ }^{90,91}$ The most important Hantavirus in Europe is Puumala serotype; others of interest are Dobrava, Saaremaa, Tula, and sporadically in Balkans, Hantan and Seoul serotypes. ${ }^{87,92-94}$ Recently, Hantavirus infections appeared especially in the Netherlands ${ }^{95}$ and Denmark (Saaremaa and Puumala). ${ }^{96}$ In Greece the Dobrava type is predominant, carried by the rodent Apodemus flavicollis. ${ }^{91}$ Puumala virus (also affecting sheep and transmitted by Clethrinomys glareolus) predominates in northern Sweden, ${ }^{97}$ in Scandinavia, ${ }^{94}$ and in Balkans. ${ }^{93}$ Dobrava and Puumala spread especially in Croatia, Serbia, Bosnia, Herzegovina, and Montenegro $^{98,99}$ as well as in Slovakia, ${ }^{100}$ and, in general, in eastern and central Europe. ${ }^{101}$ In addition, in Germany, about 600 cases of Hantavirus disease, caused mainly by Puumala, and also by Dobrava viruses, were found during the period 2001-2003, mainly in the Baden-Wurttemberg regions. ${ }^{102}$ Also, cases were found in Spain ${ }^{103}$ and especially in western Russia, where Hantaviruses are widely spread by different rodents. ${ }^{91,94}$ In Europe, the infection is generally transmitted, in addition to the Apodemus species, by the bank vole. ${ }^{101}$ After an incubation period of 2-3 weeks, different manifestations occur, depending on the viral type involved. ${ }^{98}$ In particular, Dobrava often shows haemorrhagic manifestations, Puumala and Saaremaa are more commonly associated with epidemic nephropathy. ${ }^{101}$ Minor symptoms are headache, gastrointestinal manifestations, and vertigo. ${ }^{101}$ Table 4 summarises the clinical manifestations of haemorrhagic fevers.

Diagnosis of Hantavirus is performed by immunofluorescence, ELISA, and Western blot tests (IgM detection is also possible). Typing is obtained by employing neutralisation assays or RT-PCR and sequencing techniques..$^{98,101,102}$ Whereas Puumala virus is more antigenically distinct from other 
Table 4. Etiology and clinical manifestations of emergent and re-emergent haemorrhagic fevers

\begin{tabular}{llll}
\hline Type of infection & Etiologic agent & Clinical manifestations & Geographic area \\
\hline $\begin{array}{l}\text { Crimean-Congo } \\
\text { Haemorrhagic fever }\end{array}$ & $\begin{array}{l}\text { Nairovirus } \\
\text { (Bunyaviridae) }\end{array}$ & $\begin{array}{l}\text { Fever with haemorrhage manifestations, } \\
\text { liver and kidney involvement, } \\
\text { and/or neurologic compromisation }\end{array}$ & $\begin{array}{l}\text { Western Europe, } \\
\text { France, and Portugal }\end{array}$ \\
$\begin{array}{ll}\text { Omsk virus } \\
\text { Hantavirus (Bunyavirus) }\end{array}$ & $\begin{array}{l}\text { Flavivirus } \\
\text { Bunyaviridae }\end{array}$ & $\begin{array}{l}\text { Fever with renal and/or } \\
\text { pulmonary involvement, } \\
\text { haemorrhagic manifestations }\end{array}$ & $\begin{array}{l}\text { Siberia } \\
\text { Western Russia, Central Europe, } \\
\text { Scandinavia, Spain, Netherlands, } \\
\text { Denmark, Balkans, Greece, and France }\end{array}$ \\
\hline
\end{tabular}

Hantaviruses, Dobrava, and Saaremaa are genetically and antigenically strongly correlated. ${ }^{101}$ Consequently, cross reactions are also possible in serologic detection. ${ }^{101,102}$ In this context, Sin Nombre virus (Hantavirus) deserves a special mention. It is responsible for the cardiopulmonary syndrome, first recognised in 1993 in the southwestern region of USA. The first cases were reported in Europe in 2002. ${ }^{104}$ Finally, we recall Dengue viruses that caused a severe epidemic of haemorrhagic fever during 1927-1928 in Greece, with 1200 deaths (type 1 and 2) ${ }^{105}$ and some cases of fever with arthralgia in the Mediterranean area. At present, in Europe, dengue virus is responsible for infections only in travelers from endemic regions. These cases are generally not severe and lack haemorrhagic manifestations. ${ }^{85,106,107}$

\section{ENCEPHALITIC VIRUSES EMERGING IN EUROPE}

The most important emergent and re-emergent viral encephalitides in Europe are caused by Tick borne encephalitic virus (TBEV), West Nile virus (WNV), Toscana Virus (TOSV), and Tahyna virus.

Tick Ixodes that transmits TBEV in European climates completes its development cycle in 3 years. In particular the infection is transmissible even in the nymph phase. ${ }^{108} \mathrm{TBEV}$ is present in different variants or subtypes, ${ }^{78}$ among them the two main are Sofin (eastern subtype) and Neudorfl (western subtype). The former, responsible for more severe infection, and also known as Spring-Summer Russian Encephalitis, is diffused particularly in Russia, Czech Republic, Austria, Poland, Hungary, and former Yugoslavia. The latter, responsible for a less aggressive form, called Central European Encephalitis, is diffused particularly in this geographic area, but has spread also to Austrian border regions (Italy and former Yugoslavia). In the recent years, the virus reached some Italian regions, for example, northeast and central Italy, ${ }^{109}$ and has also been reported in Piedmont (northwest region). ${ }^{110}$ Moreover, TBEV (strain Neudorfl) has been reported in Denmark, ${ }^{111}$ in Scandinavia, ${ }^{112}$ and in Greece. ${ }^{113}$ TBEV, in addition to tick bites, is also transmitted by unpasteurized milk and infected aerosols. ${ }^{78}$ Its incubation period ranges from 1 to 2 weeks. $^{78}$

In Poland, during 1993-2002, 1996 cases of TBE were reported (Kondrusik et al., 2004) ${ }^{114}$ and in Russia, over 10000 cases a year; about 3000 cases are possible in the rest of Europe. ${ }^{12,86}$ Biphasic behaviour has been observed when the central nervous system (CNS) is involved.

In Germany, during 1991-2000, 1500 patients were diagnosed for symptomatic infection of TBEV; neurologic manifestations were described in $47 \%$ of the cases $(42 \%$ with meningoencephalitis and $11 \%$ with meningoencephalomyelitis) (Table 5). The mortality was about $1 \%$, but a higher percentage of neurologic sequelae was signalled. ${ }^{115}$ More severe is the Russian type disease (Spring-summer encephalitis) with mortality also above $20 \%$ in patients with neurologic implication. ${ }^{12,86,116}$

Diagnosis of TBE can be performed by viral isolation and neutralisation tests (with hazard), or by using classical serologic tests, including complement fixation and enzyme immunoassay (EIA) for $\operatorname{IgM}$ research, ${ }^{117}$ and more recently by higher specific rE-3D enzyme-linked immunosorbent assay (rE-D3 ELISA) and Western tests. The rE-D3 ELISA permits a differential diagnosis with respect to other tick borne zoonosis. ${ }^{118}$ Also, in recent years real-time RT-PCR for detection and quantitation of TBEV RNA that also permits the strain differentiation has been used. ${ }^{119}$

Because of increasing risk for TBE infection, vaccination is suggested for subjects living or working in areas infested by ticks. ${ }^{115}$

TBE-related viruses are also sporadically present in Europe, such as Louping ill, Langat, and Powassan. Sporadic presence in Europe also occurs for haemorrhagic fever viruses partially related to the TBE complex, such as Omsk haemorrhagic fever, Kyasanur 
Table 5. Etiology and clinical manifestations of emergent and re-emergent viral encephalitis

\begin{tabular}{|c|c|c|c|}
\hline Type of infection & Etiologic agent & Clinical manifestations & Geographic area \\
\hline $\begin{array}{l}\text { Spring-summer } \\
\text { Russian encephalitis }\end{array}$ & TBEV (Sofin subtype-Flavivirus) & $\begin{array}{l}\text { Biphasic behavior: influenza-like } \\
\text { phase, followed by severe } \\
\text { neurologic involvement }\end{array}$ & Former Russian Federation \\
\hline $\begin{array}{l}\text { Central European } \\
\text { encephalitis }\end{array}$ & TBEV (Neudorfl subtype) & Less severe evolution & $\begin{array}{l}\text { Central Europe, Austria, } \\
\text { Greece, former Yugoslavia, } \\
\text { north of Italy, Denmark, } \\
\text { and Scandinavia }\end{array}$ \\
\hline West Nile disease & West Nile virus (Flavivirus) & $\begin{array}{l}\text { Asymptomatic infection, } \\
\text { aseptic meningitis, encephalitis, } \\
\text { flaccid paralysis }\end{array}$ & Russia, Romania, France \\
\hline Toscana virus disease & $\begin{array}{l}\text { Toscana virus (Phlebovirus, } \\
\text { Bunyaviridae) }\end{array}$ & $\begin{array}{l}\text { Influenza-like syndrome, aseptic } \\
\text { meningitis or meningoencephalitis }\end{array}$ & $\begin{array}{l}\text { Mediterranean basin, } \\
\text { Portugal, Spain, France, } \\
\text { Cyprus }\end{array}$ \\
\hline Thayna virus disease & $\begin{array}{l}\text { Thayna virus (California } \\
\text { group Bunyavirus) }\end{array}$ & Encephalitis & $\begin{array}{l}\text { Southern Russia Germany, } \\
\text { Czech Republic, Netherlands, } \\
\text { and Balkans }\end{array}$ \\
\hline Enteroviral infections & $\begin{array}{l}\text { ECHO }(6,13,30) \text { Coxsackie } \\
\text { A16 Enterovirus } 71 \text { (Picornavirus) }\end{array}$ & Meningitis, encephalitis & $\begin{array}{l}\text { Belgium, France, Germany, } \\
\text { Scandinavia }\end{array}$ \\
\hline
\end{tabular}

Forest disease and Alkhurma agents that occasionally may cause encephalitis. ${ }^{12,86}$

West Nile fever is a mosquito-transmitted viral infection, emergent and subsequently re-emergent in Europe from the first half of the 1960s, particularly in Western Mediterranean areas and southern Russia. ${ }^{120}$ Recently, the infection reached Germany, Denmark, and Scandinavia, with increased incidence of encephalitic diseases. ${ }^{35,121}$ WNV may cause fever and sometimes encephalitis in large mammals, especially in horses and also in humans. ${ }^{120,122,123}$ Reservoirs are wild (often migratory) and domestic birds; mosquito vectors (generally belonging to Culex genus) may also act as reservoirs. In fact, transovaric transmission of the infection is also possible. ${ }^{124}$ Extravectorial infection in animals ${ }^{125}$ and even by blood transfusion in humans, ${ }^{126}$ or consequent to organ transplants have been reported. ${ }^{127,128}$

The virus was first isolated in Africa (West Nile District of Uganda, 1937) and originally produced a prevalently febrile disease and acquired neurotropism during the second half of the 20th century. ${ }^{129}$ It seems that the death of Alexander the Great in Babylon at the age of 32 was the result of a serious febrile disease, in reality he was affected by WNV encephalitis. ${ }^{130}$ During 1999, the virus reached northeastern United States, New York City, and subsequently also the West Coast of USA, and Canada. ${ }^{129,131}$

A peculiar characteristic of West Nile epidemic in the USA and in Europe was the involvement of urban areas where the virus was transmitted by the house mosquito, Culex pipiens. ${ }^{129}$ In particular, in USA the infection is associated with fatal diseases of crows, so demonstrating an evolution of the agent virulence; ${ }^{129,132}$ moreover, since 1999 the infection has affected thousands of subjects. ${ }^{133}$ The highest incidence was during 2003 with 9000 cases and 200 deaths. ${ }^{128}$ Moreover in USA, Canada, and Mexico the total cases reported from 2002 to October 2004 reached $16000 .{ }^{134}$ However, during 2005, in North America a decrease in the number of cases was observed and a mean seropositivity from 2 to $5 \%$ was detected in the population. ${ }^{135}$ The particular aggressiveness of West Nile infection is correlated with the fact that the viral strains, already previously present in Asia, recently underwent an incidence and virulence increase in their diffusion to western areas. ${ }^{136} \mathrm{In}$ particular, in Europe, we recall the important epidemics in Romania and in Russia, especially in the Volgograd region. In the first case the virus circulated in the southern regions from the 1960s or earlier. However, an unexpected epidemic broke out in Bucharest during the summer of 1996 (393 hospitalized cases and 17 deaths). Moreover, a novel introduction of WNV occurred during 1997-2000 with 39 human cases. ${ }^{137}$ In Russia, the epidemic occurred in July-October 1999 in the Volgograd Region with more than 800 cases of symptomatic infection and 84 cases of meningoencephalitis (40 fatal). ${ }^{138}$ In addition in France, an equine epizootic epidemic was described in the Camargue in 2000, and six human cases were detected in the French Mediterranean coast. ${ }^{139}$ Neurologic manifestations of West Nile disease that occurs in temperate areas 
during mosquito seasons may present an aseptic meningitis, meningoencephalitis, encephalitis, or encephalomyelitis accompanied by ophthalmologic manifestations (Table 5). Moreover, both the central and peripheral nervous systems may be involved. Flaccid paralysis is one of the most frequent sequelae, and no specific therapy exists for this infection. ${ }^{131,133}$ However, in humans, $80 \%$ of infections are asymptomatic, about $20 \%$ of the infections are present as an influenza-like disease whereas less than $1 \%$ of infections may cause disorders of CNS, with a mortality rate of $15 \% .{ }^{140}$ Promising experimental results have been obtained with interferon $\alpha$ and specific immunoglobulins' administrations. ${ }^{128}$ A high degree of relative lymphopenia at the onset, elevation of serum ferritin, and advanced age of affected persons may predict an unfavourable evolution.

For laboratory diagnosis, an ELISA test using the recombinant antigen (preM/E,) can be easily employed to detect IgM and IgG against WNV. ${ }^{141}$ At present vaccines, attenuated or recombinant or chimeric ones, are available only for animals. ${ }^{142}$ In fact, 150 bird species and 30 mammalian species are susceptible to WNV. In particular, some species of birds and lemurs, hamsters, and frogs may be a reservoir of the virus. ${ }^{142}$
TOSV is a neurotropic arbovirus first isolated in Tuscany during the early 1980s by Professor Paola Verani of the Italian Istituto Superiore di Sanità. This infective agent belongs to the Sandfly fever group viruses (genus Phlebovirus, family Bunyaviridae) that are transmitted by Phlebotomus vectors. TOSV is diffused in the Mediterranean basin (especially Italy, Portugal, Spain, France, and Cyprus) and may cause aseptic meningitis, meningoencephalitis and encephalitis ${ }^{143-148}$ (Table 5). Laboratory diagnosis is made by PCR techniques and immunoenzymatic tests. ${ }^{144,145,149}$ The latter permits the detection of IgG and IgM subclass in sera and cerebrospinal fluid. ${ }^{146}$ Other sandfly fever viruses, diffused in some areas of continental Africa, in middle east, and central Asia, differ from TOSV by not being endowed with neurotropism. ${ }^{150}$

Thayna, together with Batai and Inkoo viruses, can be considered to be an emergent arbovirus (Bunyavirus genus, Bunyaviridae family). These viruses are correlated with California encephalitis subgroup and have been sporadically identified in Europe, especially in southern Russia, ${ }^{151,152}$ Germany, Czech Republic, and Netherlands (prevalently Thayna), ${ }^{153}$ in Balkans, ${ }^{154}$ and rarely in other regions of southern Europe. In particular, in the Czech Republic,

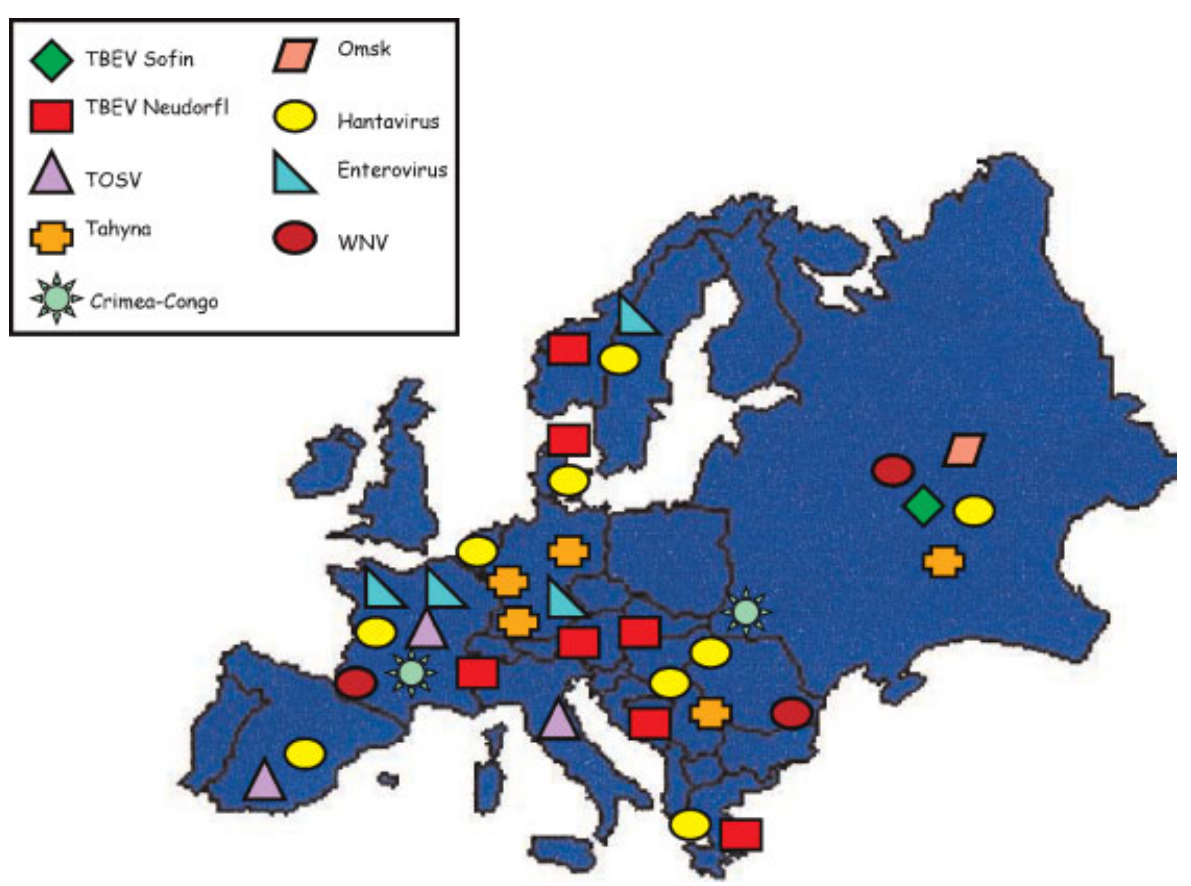

Figure 1. Main emergent, re-emergent viral infections in Europe [This figure is available in colour online at www.interscience.wiley.com] 
seroprevalence for Tahyna virus in an area affected by flood was $16 \%$ in 2002. ${ }^{155}$ These viruses are transmitted by various mosquito species, and their incidence increase at times of flood events. ${ }^{154,155}$ Monitoring of vectors and their rate of infection is useful for prophylactic measures, as for other arbovirus infections. ${ }^{154}$

In addition, non-poliomyelitic neurotropic enteroviruses can behave, from time to time, as emerging/ re-emerging viruses. From May to September 2000, an outbreak of aseptic meningitis caused by some Enterovirus strains occurred in Belgium. In particular, there was a high prevalence of Echovirus 13 (23.8\% of cases), previously considered a rare serotype. ${ }^{156}$ Moreover, encephalitis caused by Enterovirus 71 was recently described in Germany. ${ }^{157}$ Finally, neurologic manifestations caused by ECHO 30, ECHO 6, and Coxsackievirus A16 were reported in Scandinavia, ${ }^{158}$ and by ECHO 30 in France. ${ }^{159}$

\section{CONCLUDING REMARKS}

Emergent and re-emergent viral infections are historically a major and crucial concern for biologists, epidemiologists, infectivologists, and veterinarians. Today's globalised and interconnected world enhances several social, political, and economic factors allowing viral pathogens rapid and easy access to new environments and populations.

Over the past decade, new viral agents have spread at an alarming rate, including Hantavirus, Metapneumovirus, and Coronavirus that causes SARS. In addition, previously recognised viral infections such as WNV disease and Rift valley fever have emerged in new continents. The modification in reservoir host environment and adaptation of viral agents to new hosts are the main causes of pattern modification of these infections in the world. Figure 1 summarises the main emergent and re-emergent viral infections in Europe.

The lessons that we have learned from emergent and re-emergent infections in Europe may be based summarised by the four crucial features: (i) global surveillance with alert systems to monitor outbreaks and epidemics early; (ii) prevention by use of old and new vaccines; (iii) employment of scarce antiviral drugs for treatment and prevention of emergent and reemergent viral infections; and (iv) awareness of change of environment, viral agents (mutations), and adoption of public health measures.

Only a strict approach to these crucial points in future will be able to control and greatly reduce the emergence, and particularly re-emergence, of severe and deadly viral infections.

\section{ACKNOWLEDGEMENTS}

This work was supported by Italian Ministry of Public Education, University and Scientific Research.

\section{REFERENCES}

1. Pang T, Guindon GE. Globalization and risks to health. EMBO Reports 2004; 5: S11-S16.

2. McMichael AJ. Environmental and social influences on emerging infectious diseases: past, present and future. Philos Trans $R$ Soc London B Biol Sci 2004; 359: 1049-1058.

3. Trampuz A, Prabhu RM, Smith TF, Baddour LM. Avian influenza: a new pandemic threat? Mayo Clin Proc 2004; 79: 523530.

4. Sutherst RW. Global change and human vulnerability to vectorborne diseases. Clin Microbiol Rev 2004; 17: 136-173.

5. Niaussat PM. 16th century: suffering and disease on the way to great discoveries; from Lisbon to the Moluccas and to Japan. Bull Soc Pathol Exot 1999; 95: 399-404.

6. Krilov LR. Emerging infectious disease issues in international adoptions: severe acute respiratory syndrome (SARS), avian influenza and measles. Curr Opin Infect Dis 2004; 17: 391-395.

7. Snell NJ. Novel and re-emerging respiratory infections. Expert Rev Anti Infect Ther 2004; 2: 405-412.

8. Charrel RN, de Lamballerie X. West Nile virus, an emerging arbovirus. Presse Med 2004; 33: 1521-1526.

9. Fooks AR, Brookes SM, Johnson N, McElhinney LM, Hutson AM. European bat lyssaviruses: an emerging zoonosis. Epidemiol Infect 2003; 13: 1029-1039.

10. Galama JM. Emergent viral infections. Ned Tijdschr Geneeskd 2001; 145: 616-619.

11. Kuiken T, Fouchier R, Rimmelzwaan G, Osterhaus A. Emerging viral infections in a rapidly changing world. Curr Opin Biotechnol 2003; 14: 641-646.

12. Gritsun TS, Lashkevich VA, Gould EA. Tick-borne encephalitis. Antiviral Res 2003; 57: 129-146. (a).

13. Chastel C, Bailly-Choumara H, Bach-Hamba D, et al. Ticktransmitted arbovirus in Magreb. Bull Soc Pathol Exot 1995; 88: $81-85$.

14. Maki DG. SARS revisited: the challenge of controlling emerging infectious diseases at the local, regional, federal, and global levels. Mayo Clin Proc 2004; 79: 1359-1366.

15. Bossi P, Guihot A, Ansart S, Bricaire F. Severe acute respiratory syndrome: update. Rev Med Interne 2003; 24: 672-680.

16. Tse GM, To KF, Chan PK, et al. Pulmonary pathological features in coronavirus associated severe acute respiratory syndrome (SARS). J Clin Pathol 2004; 57: 260-265.

17. Hung IF, Cheng VC, Wu AK, et al. Viral loads in clinical specimens and SARS manifestations. Emerg Infect Dis 2004; 10: $1550-1557$.

18. Booth CM, Matukas LM, Tomlinson GA, et al. Clinical features and short-term outcomes of 144 patients with SARS in the greater Toronto area. JAMA 2003; 289: 2801-2809.

19. Fowler RA, Lapinsky SE, Hallett D, et al. Toronto SARS Critical Care Group. Critically ill patients with severe acute respiratory syndrome. JAMA 2003; 290: 367-373. 
20. Del Rey Calero J. Epidemiological perspectives on SARS and avian influenza. An R Acad Nac Med (Madr) 2004; 121: 289304.

21. Martina BE, Haagmans BL, Kuiken T, et al. Virology: SARS virus infection of cats and ferrets. Nature 2003; 425: 915.

22. Xu HF, Wang M, Zhang ZB, et al. An epidemiologic investigation on infection with severe acute respiratory syndrome coronavirus in wild animals traders in Guangzhou. Zhonghua Yu Fang Yi Xue Za Zi 2004; 38: 81-83.

23. Poon LL, Chu DK, Chan KH, et al. Identification of a novel coronavirus in bats. J Virol 2005; 79: 2001-2009.

24. Ooi GC, Khong PL, Muller NL, et al. Severe acute respiratory syndrome: temporal lung changes at thin-section CT in 30 patients. Radiology 2004; 230: 836-844.

25. Sainz B, Jr, Mossel EC, Peters CJ, Garry RF. Interferon-beta and interferon-gamma synergistically inhibit the replication of severe acute respiratory syndrome-associated coronavirus (SARS-CoV). Virology 2004; 329: 11-17.

26. Ali MB. Treating severe acute respiratory syndrome with hyperimmune globulins. Hong Kong Med J 2003; 9: 391- 392.

27. Kuba K, Imai Y, Rao S, et al. A crucial role of angiotensin converting enzyme 2 (ACE2) in SARS coronavirus-induced lung injury. Nat Med 2005; 11: 875-879.

28. Liang G, Chen Q, Xu J, et al. Laboratory diagnosis of four recent sporadic cases of community-acquired SARS, Guangdong Province, China. Emerg Infect Dis 2004; 10: 1774-81.

29. Hsueh PR, Huang LM, Chen PJ, Kao CL, Yang PC. Chronological evolution of $\operatorname{IgM}, \operatorname{Ig} \mathrm{A}, \operatorname{IgG}$ and neutralisation antibodies after infection with SARS-associated coronavirus. Clin Microbiol Infect 2004; 10: 1062-1066.

30. Guan M, Chan KH, Peiris JS, et al. Evaluation and validation of an enzyme-linked immunosorbent assay and an immunochromatographic test for serological diagnosis of severe acute respiratory syndrome. Clin Diagn Lab Immunol 2004; 11: 699-703.

31. Desenclos JC, van der Werf S, Bonmarin I, et al. Introduction of SARS in France, March-April, 2003. Emerg Infect Dis 2004; 10: $195-200$.

32. Rickerts V, Wolf T, Rottmann C, et al. Clinical presentation and management of the severe acute respiratory syndrome (SARS). Dtsch Med Wochenschr 2003; 128: 1109-1114.

33. Petrosillo N, Puro V, Ippolito G. Border screening for SARS. MJA (Medical Journal of Australia) 2004; 180: 597-598.

34. Brug J, Aro AR, Oenema A, De Zwart O, Richardus JH, Bishop GD. SARS risk perception, knowledge, precautions, and information sources, the Netherlands. Emerg Infect Dis 2004; 10: 1486-1489.

35. Haas W, Krause G, Marcus U, Stark K, Ammon A, Burger R. "Emerging infectious diseases". Dengue-fever, West-Nile fever, SARS, avian influenza, HIV. Internist (Berl) 2004; 45: 684-692.

36. Chastel C. Emergence of new viruses in Asia: is climate change involved? Med Mal Infect 2004; 34: 499-505.

37. Capua I, Alexander DJ. Avian influenza and human health. Acta Trop 2002; 83: 1-6.

38. Daszak P, Tabor GM, Kilpatrick AM, Epstein J, Plowright R. Conservation medicine and a new agenda for emerging diseases. Ann NY Acad Sci 2004; 1026: 1-11.

39. Kaye D, Pringle CR. Avian influenza viruses and their implication for human health. Clin Infect Dis 2005; 40: 108-112.

40. Ungchusak K, Auewarakul P, Dowell SF, et al. Probable personto-person transmission of avian influenza A (H5N1). N Engl J Med 2005; 352: 333-340.
41. Chen H, Deng G, Li Z, et al. The evolution of H5N1 influenza viruses in ducks in southern China. Proc Natl Acad Sci USA 2004; 101: 10452-10457.

42. Puthavathana P, Auiewarakul P, Charoenying PC, et al. Molecular characterization of the complete genome of human influenza $\mathrm{H} 5 \mathrm{~N} 1$ virus isolates from Thailand. J Gen Virol 2005; 86: 423-433.

43. Liu JH, Okazaki K, Shi WM, Kida H. Phylogenetic analysis of hemagglutinin and neuraminidase genes of H9N2 viruses isolated from migratory ducks. Virus Genes 2003; 27: 291-296.

44. Bowes VA, Ritchie SJ, Byrne S, Sojonky K, Bidulka JJ, Robinson JH. Virus characterization, clinical presentation, and pathology associated with $\mathrm{H} 7 \mathrm{~N} 3$ avian influenza in British Columbia broiler breeder chickens in 2004. Avian Dis 2004; 49: 928-934.

45. Koopmans M, Wilbrink B, Conyn M, et al. Transmission of H7N7 avian influenza a virus to human beings during a large outbreak in commercial poultry farms in the Netherlands. Lancet 2004; 363: 587-593.

46. Okazaki K, Takada A, Ito T, et al. Precursor genes of future pandemic influenza viruses are perpetuated in ducks nesting in Siberia. Arch Virol 2000; 145: 885-893.

47. Van Borm S, Thomas I, Hanquet G, et al. Highly pathogenic H5N1 influenza virus in smuggled Thai eagles, Belgium. Emerg Infect Dis 2005; 11: 702-705.

48. Timen A, van Vliet JA, Koopmans MP, van Steenbergen JE, Coutinho RA. Avian influenza H5N1 in Europe: little risk as yet to health in the Nether-lands. Net Tijdschr Geneeskd 2005; 149: 2547-2549.

49. Alexander DJ. Report on avian influenza in the Eastern Hemisphere during 1997-2002. Avian Dis 2003; 47 (3S): 792-797.

50. Marangon S, Capua I, Pozza G, Santucci U. Field experiences in the control of avian influenza outbreaks in densely populated poultry areas. Dev Biol (Basel) 2004; 119: 155-164.

51. Fouchier RA, Schneeberger PM, Rozendaal FW, et al. Avian influenza A virus (H7N7) associated with human conjunctivitis and a fatal case of acute respiratory distress syndrome. Proc Natl Acad Sci USA 2004; 101: 1356-1361.

52. Bush RM. Influenza as a model system for studying the crossspecies transfer and evolution of the SARS coronavirus. Philos Trans R Soc Lond Biol Sci 359: 1067-1073.

53. Wong SS, Yuen KY. Avian influenza virus infections in humans. Chest 2006; 129: 156-168.

54. Arostegi Karega N, Montes M, Perez-Yarza EG, Sardon O, Vincente D, Cilla G. Clinical characteristics of children hospitalized for influenza virus infection. An Pediatr (Barc) 2005; 62: 5-12.

55. Kauffman RS. Viral pneumonia. In Respiratory infections: diagnosis and management. Pennington JE (ed.). Raven Press: New York, 1983; 317-328.

56. Brydak LB. Neurological complication of influenza infections. Przegl Epidemiol 2002; 56 (S1): 16-30.

57. Maisch B, Ristic AD, Portig I, Pankuweit S. Human viral cardiomyopathy. Front Biosci 2003; 8: s39-76.

58. Whitney CG, Harper SA. Lower respiratory tract infections: prevention using vaccines. Infect Dis Clin North Am 2004; 18: 899-917.

59. Yuen KY, Chan PK, Peiris M, et al. Clinical features and rapid viral diagnosis of human disease associated with avian influenza A H5N1 virus. Lancet 1998; 351: 467-471.

60. Tran TH, Nguyen TL, Nguyen TD, et al. avian influenza A (H5N1) in 10 patients in Vietnam. $N$ Engl J Med 2004; 350: $1179-1188$. 
61. Amano Y, Cheng Q. Detection of influenza virus: traditional approaches and development of biosensors. Anal Bioanal Chem 2005; 381: 156-164.

62. Bridges CB, Winquist AG, Fukuda K, Cox NJ, Singleton JA, Strikas RA. Advisory Committee on Immunization Practices. Prevention and control of influenza: recommendations of the Advisory Committee on Immunization Practices (ACIP). MMMWR Recomm Rep 2000; V 49 (RR-3): 1-38.

63. Vindt Holm M, Gyldmark M, Holme Hansen E. Pharmacoeconomic assessment of oseltamivir in treating influenza-the case of otherwise healthy Danish adolescents and adults. Pharm World Sci 2004; 26: 339-345.

64. De Jong MD, Tran TT, Truong HK, et al. Oseltamivir resistance during treatment of influenza A (H5N1) infection. $N$ Engl J Med 2005; 353: 2667-2672.

65. Hayden F, Klimov A, Tashiro M, et al. Neuraminidase inhibitor susceptibility network position statement: antiviral resistance in influenza A/H5N1 viruses. Antivir Ther 2005; 10: 873-877.

66. Center for Disease Control and prevention (CDC). High levels of adamantane resistance among influenza A (H3N2) viruses and interim guidelines for use of antiviral agents-United States, 2005-2006 influenza season. MMWR Morb Mortal Wkly Rep 2006; 55: 44-46.

67. Gerdil C. The annual production cycle for influenza vaccine. Vaccine 2003; 21: 1776-1779.

68. Rimmelzwaan GF, de Jong JC, Bartelds AI, Wilbrink B, Fouchier RA, Osterhaus AD. The 2003/2004 influenza season in the Netherlands with a limited epidemic of the virus variant A//Fujian, and vaccine composition for the 2004/2005 season. Ned Tijdschr Geneeskd 2004; 148: 1984-1988.

69. Van Kampen KR, Shi Z, Gao P, et al. Safety and immunogenicity of adenovirus-vectored nasal and epicutaneous influenza vaccines in humans. Vaccine 2005; 23: 1209-1236.

70. Wiczynski J, Litwinska B. Human metapneumovirus-new identified virus infecting human respiratory tract. Pregl Epidemiol 2004; 58: 325-333.

71. Takahashi M, Saegusa T, Umeya T, Mori M. Epidemic pleurodinia at a high school. Nippon Naika Gakkai Zasshi 2004; 93: 1180-1182.

72. Chan YF, AbuBaker S. Recombinant human enterovirus 71 in hand, foot and mouth disease patients. Emerg Infect Dis 2004; 10: $1468-1470$.

73. Matthews L, Woolhouse M. New approaches to quantifying the spread of infection. Nat Rev Microbiol 2005; 3: 529-536.

74. Hsiung GD, Wang JR. Enterovirus infections with special reference to enterovirus 71. J Microbiol Immunol Infect 2000; 33: $1-8$

75. Welch J, Maclaran K, Jordan T, Simmonds P. Frequency, viral loads, and serotype identification of enterovirus infections in Scottish blood donors. Transfusion 2003; 43: 1060-1066.

76. Wang SM, Lei HY, Huang MC, et al. Therapeutic efficacy of mileinone in the management of enterovirus 71-induced pulmonary edema. Pediatr Pulmonol 2005; 39: 219-223.

77. Faix DJ, Houng HS, Gaydos JC, et al. Evaluation of a rapid quantitative diagnostic test for adenovirus type 4. Clin Infect Dis 2004; 38: 391-397.

78. Charrel RN, Attoui H, Butenko AM, et al. Tick-borne virus diseases of human interest in Europe. Clin Microbiol Infect 2004; 10: 1040-1055.

79. Kuhn JH, Seregin SV, Morzunov SP, et al. Genetic analysis of the M RNA segment of Crimean-Congo haemorrhagic fever virus strains involved in the recent outbreaks in Russia. Arch Virol 2004; 149: 2199-2213.
80. Papa A, Christova I, Papadimitriou E, Antoniadis A. CrimeanCongo haemorrhagic fever in Bulgaria. Emerg Infect Dis 2004; 10: $1465-1467$.

81. Lopez-Velez R, Molina Moreno R. Climate change in Spain and risk of infectious and parasitic diseases transmitted by arthropods and rodents. Rev Esp Salud Publica 2005; 79: 177-190.

82. Whitehouse CA. Crimean-Congo hemorragic fever. Antiviral Res 2004; 64: 145-160.

83. Busygin FF. Omsk haemorrhagic fever-current status of the problem. Vopr Virusol 2000; 45: 4-9.

84. Charrel RN, de Lamballerie X. The Alkhurma virus (family Flaviviridae, genus Flavivirus): an emerging pathogen responsible for hemorrhage fever in the Middle East. Med Trop (Mars) 2003; 63: 296-299.

85. Solomon T, Mallewa M. Dengue and other emerging flaviviruses. J Infect 2001; 42: 104-115.

86. Gritsun TS, Nuttall PA, Gould EA. Tick-borne flaviviruses. $A d v$ Virus Res 2003; 61: 317-371. (b).

87. Clement J, Heyman P, McKenna P, Colon P, Avsic-Zupanc T. The hantaviruses of Europe: from the bedside to the bench. Emerg Infect Dis 1997; 3: 205-211.

88. Gegundez MI, Lledo L. Infection due to Hantavirus and other rodent-borne viruses. Enferm Infect Microbiol Clin 2005; 23: 492-500.

89. Simmons JH, Riley LK. Hantaviruses: an overview. Comp Med 2002; 52: 97-110.

90. Papa A, Antoniadis A. Hantavirus infections in Greece-an update. Eur J Epidemiol 2001; 17: 189-194.

91. Dekonenko AE, Tkachenko EA. Hantaviruses and hantavirus infections. Vopr Virusol 2004; 49: 40-44.

92. Sjolander KB, Golovljova I, Vasilenko V, Plyusnin A, Lundkvist A. Serological divergence of Dobrava and Saaremaa hantaviruses: evidence for two distinct serotypes. Epidemiol Infect 2002; 128: 99-103.

93. Khan A, Khan AS. Hantaviruses: a tale of two hemispheres. Panminerva Med 2003; 45: 43-51.

94. Strady C, Jaussaud R, Remy G, Penalba C. Hantavirus infections. Presse Med 2005; 34: 391-399.

95. Van der Poel WH. "Emerging" viral zoonoses in native animals who can be the host in the Netherlands. Tijdschr Diergeneeskd 1999; 124: 3-11.

96. Nemirov K, Andersen HK, Leirs H, et al. Saaremaa hantavirus in Denmark. J Clin Virol 2004; 30: 254-257.

97. Olsson GE, Dalerum F, Honfeldt B, et al. Human hantavirus infections, Sweden. Emerg Infect Dis 2003; 9: 1395-1401.

98. Puljiz I, Kuzman I, Turcinov D, Markotic A, Celjuska E. Clinical and epidemiologic characteristics of haemorrhagic fever with renal syndrome in patients treated at the Dr. Fran Miihaljevic Clinic for Infectious Diseases in Zagreb. Acta Med Croatica 2003; 57: 347-353.

99. Mulic R, Ropac D, Gizdic Z, Sikic N. What is new in the epidemiologic characteristics of haemorrhagic fever with renal syndrome in Croatia? Acta Med Croatica 2003; 57: 399-405.

100. Klempa B, Stanko M, Labuda M, Ulrich R, Meisel H, Kruger DH. Central European Dobrava Hantavirus isolate from a striped field mouse (Apodemus agrarius). J Clin Microbiol 2005; 43: 2756-2763

101. Vapalahti O, Mustonen J, Lundkvist A, Henttonen H, Plysnin A, Vaheri A. Hantavirus infections in Europe. Lancet Infect Dis 2003; 3: 653-661.

102. Ulrich R, Meisel H, Schutt M, et al. Prevalence of hantavirus infections in Germany. Bundesgesundheitsblatt Gesundheitsforschung Gesundheitsschutz 2004; 47: 661-670. 
103. Garcia Nieto A, Medina Blanco G, Reinares Otriz de Villajos J. Emerging zoonoses linked to pets in the autonomous community of Madrid: design of a method for setting public health priorities, Spain. Rev Esp Salud Publica 2004; 78: 389398.

104. Schmidt J, Meisel H, Hjelle B, Kruger DH, Ulrich R. Development and evaluation of serological assays for detection of human hantavirus infections caused by Sin Nombre virus. $J$ Clin Virol 2005: 33: 247-253.

105. Rosen L. Dengue in Greece in 1927 and 1928 and the pathogenesis of dengue haemorrhagic fever: new data and a different conclusion. Am J Trop Med Hyg 1986; 35: 642-653.

106. Haas W, Krause G, Marcus U, Stark K, Ammon A, Burger R. «Emerging infectious diseases». Dengue-fever, West-Nile, SARS, avian influenza, HIV. Internist (Berl) 2004; 45: 684692.

107. Frank C, Schonenberg I, Krause G, Claus H, Ammon A, Stark K. Increase in imported dengue, Germany. 2001-2002. Emerg Infect Dis 2004; 10: 903-906.

108. Rizzoli A, Rosa R, Mantelli B, et al. Ixodes ricinus, transmitted diseases and reservoirs. Parassitologia. 2004; 46: 119122.

109. Cinco M, Barbone F, Ciufolini MG, et al. Seroprevalence of tick-borne infections in forestry rangers from northeastern Italy. Clin Microbiol Infect 2004; 10: 1056-1061.

110. Pugliese A, Beltramo T, Torre D. Seroprevalence study of Tick Borne Encephalitis, Borrelia burgdorferi, Dengue and Toscana virus in Turin Province. Cell Biochem Funct (in press).

111. Skarphedinsson S, Jensen PM, Kristiansen K. Survey in tickborne infections in Denmark. Emerg Infect Dis 2005; 11: 1055-1061.

112. Haglund M, Vene S, Forsgren $\mathrm{M}$, et al. Characterization of human tick-borne encephalitis virus from Sweden. J Med Virol 2003; 71: 610-621.

113. Jaussaud R, Magy N, Strady A, Dupond JL, Deville JF. Tickborne encephalitis. Rev Med Interne 2001; 22: 542-548.

114. Kondrusik M, Biedzinska T, Pancewicz S, et al. Tick-borne encephalitis (TBE) cases in Bialostocki and Podlaski regions in 1993-2002 years. Przegl Epidemiol 2004; 58: 273280.

115. Kaiser R. Tick-borne encephalitis (TBE) in Germany and clinical course of the disease. Int J Med Microbiol 2002; 291 (S.33): 58-61.

116. Seligman SJ, Gould EA. Life flavivirus vaccines: reasons for caution. Lancet 2004; 363: 2073-2075.

117. Sambri V, Marangoni A, Storni E, et al. Tick borne zoonosis: selected clinical and diagnostic aspects. Parassitologia 2004; 46: 109-113.

118. Holbrook MR, Shope RE, Barrett AD. Use of recombinant E protein domain III-based enzyme-linked immunosorbent assays for differentiation of tick-borne encephalitis serocomplex flaviviruses from mosquito-borne flaviviruses. J Clin Microbiol 2004; 42: 4101-4110.

119. Schwaiger M, Cassinotti P. Development of a quantitative realtime RT-PCR assay with internal control for the laboratory detection of tick borne encephalitis virus (TBEV) RNA. J Clin Virol 2003; 27: 136-145.

120. Hubalek Z, Halouzka J. West Nile fever-a reemerging mosquito-borne viral disease in Europe. Emerg Infect Dis 1999; 5: 643-650.

121. Knudsen TB, Andersen O, Kronborg G. Death from the Nile crosses the Atlantic: the West Nile Fever story. Scand J Infect Dis 2003; 35: 820-825.
122. Kramer LD, Bernard KA. West Nile virus in the western hemisphere. Curr Opin Infect Dis 2001; 14: 519-525 a.

123. Cantile C, Di Guardo G, Eleni C, Arispici M. Clinical and neuropathological features of West Nile virus equine encephalomyelitis in Italy. Equine Vet J 2000; 32: 31-35.

124. Kramer LD, Bernard KA. West Nile virus in birds and mammals. Ann NY Acad Sci 2001; 951: 84-93 b.

125. Kuno G. Transmission of arboviruses without involvement of arthropod vectors. Acta Virologica 2001; 45: 139-150.

126. Hollinger FB, Kleinman S. Transfusion transmission of West Nile virus: a merging of historical and contemporary perspectives. Transfusion 2003; 43: 992-997.

127. Weiskittel PD. West Nile virus infection in a renal transplant recipient. Nephrol Nurs J 2004; 31: 327-329.

128. Gea-Banacloche J, Johnson RT, Bagic A, Butman JA, Murray PR, Agrawal AG. West Nile virus: pathogenesis and therapeutic options. Ann Intern Med 2004; 140: 545-553.

129. Hayes CG. West Nile virus: Uganda. 1937, to New York City, 1999. Ann NY Acad Sci 2001; 951: 25-37.

130. Marr JS, Calisher CH. Alexander the Great and West Nile virus encephalitis. Emerg Infect Dis 2003; 9: 1599-1603.

131. Burton JM, Kern RZ, Halliday W, et al. Neurological manifestations of West Nile virus infection. Can J Neurol Sci 2004; 31: 185-193.

132. Brault AC, Langevin SA, Bowen RA, et al. Differential virulence of West Nile strains for American crows. Emerg Infect Dis 2004; 10: 2161-2168.

133. Cunha BA. Differential diagnosis of west Nile encephalitis. Curr Opin Infect Dis 2004; 17: 413-420.

134. Charrel RN, de Lamballerie X. West Nile virus, an emerging arbovirus. Presse Med 2004; 33: 1521-1526.

135. Everson K. West Nile virus up to 2005. CMAJ 2006; 174: 21.

136. Lvov DK, Butenko AM, Gromashevsky VL, et al. West Nile virus and other zoonotic viruses in Russia: examples of emerging-reemerging situations. Arch Virol Suppl 2004; 18: $85-96$.

137. Campbell GL, Ceianu CS, Savage HM. Epidemic West Nile encephalitis in Romania: waiting for history to repeat itself. Ann NY Acad Sci 2001; 951: 94-101.

138. Platonov AE, Shipulin GA, Shipulina OY, et al. Outbreak of West Nile virus infection, Volgograd region, Russia, 1999. Emerg Infect Dis 2001; 7: 128-132.

139. Durand JP, Simon F, Tolou H. West Nile virus: in France again, in humans and horses. Rev Prat 2004; 54: 703-710.

140. Dean JL, Palermo BJ. West Nile virus encephalitis. Curr Infect Dis Rep 2005; 7: 292-296.

141. Hogrefe WR, Moore R, Lape-Nixon M, Wagner M, Prince HE. Performance of immunoglobulin G (IgG) and IGM enzymelinked immunosorbent assays using a West Nile virus recombinant antigen (preM/E) for detection of West Nile virus-and other flavivirus-specific antibodies. J Clin Microbiol 2004; 42: 4641-4648.

142. Van der Meulen KM, Pensaert MB, Nauwynck HJ. West Nile virus in the vertebrate world. Arch Virol 2005; 150: 637-657.

143. Portolani M, Sabbatini AM, Beretti F, Gennari W, Tamassia MG, Pecorari M. Symptomatic infections by Toscana virus in the Modena province in the triennium 1999-2001. New Microbiol 2002; 25: 485-458.

144. Valassina M, Cusi MG, Valensin PE. A Mediterranean arbovirus: the Toscana virus. J Neurovirol 2003; 9: 577-583. a.

145. Valassina M, Valentini M, Pugliese A, Valensin PE, Cusi MG. Serological survey of Toscana virus infections in a high-risk population in Italy. Clin Diagn Lab Immunol 2003; 10: 483484. b. 
146. Beersma MF, Grimbergen YA, Kroon FP, Veldkamp PJ. Meningitis caused by Toscana virus during a summer stay in Italy. Ned Tijdscr Geneeskd 2004; 148: 286-288.

147. Echevarria JM, de Ory F, Guisasola ME, et al. Acute meningitis due to Toscana virus infection among patients from both the Spanish Mediterranean region and the region of Madrid. J Clin Virol 2003; 26: 79-84.

148. Peyrefitte CN, Devetakov I, Pastorino B, et al. Toscana virus and acute meningitis, France. Emerg Infect Dis 2005; 11: 778-780.

149. Sanchez-Seco MP, Echevarria JM, Hernandez L, Estevez D, Navarro-Mari JM, Tenorio A. Detection and identification of Toscana and other phleboviruses by RT-nested-PCR assays with degenerated primers. J Med Virol 2003; 71: 140-149.

150. Dionisio D, Esperti F, Vivarelli A, Valassina M. Epidemiological, clinical and laboratory aspects of sandfly fever. Curr Opin Infect Dis 2003; 16: 383-388.

151. Vanlandingham DL, Davis BS, Lvov DK, et al. Molecular characterization of California serogroup viruses isolated in Russia. Am J Trop Med Hyg 2002; 67: 306-309.

152. Korobeinikova AS, Nafeev AA, Skvortsova TM. Specific markers for the detection of circulating of Tahyna, Inko and Batai viruses (Bunyaviridae, Bunyavirus) in humans, mosquitoes, ticks and cattle of the Ul'ianovsk region. Vopr Virusol 2003; 48: 45-46.
153. Pilaski J, Mackenstein H. Isolation of Tahyna virus from mosquitoes in 2 different European natural foci. Zentralbl Bakteriol Mikrobiol Hyg 1985; 180: 394-420.

154. Hubalek Z, Zeman P, Halouzka J, et al. Antibodies against mosquito-born viruses in human population of an area of Central Bohemia affected by the flood of 2002. Epidemiol Mikrobiol Immunol 2004; 53: 112-120.

155. Hubalek Z, Zeman P, Halouzka J, et al. Mosquito-borne viruses, Czech Republic, 2002. Emerg Infect Dis 2005; 11: $116-118$.

156. Thoelen I, Lemey P, Van Der Donck I, Beuselinck K, Lindberg AM, Van Ranst M. Molecular typing and epidemiology of enteroviruses identified from an outbreak of aseptic meningitis in Belgium during the summer of 2000. J Med Virol 2003; 70: 420-429.

157. Kehle J, Roth B, Metzger C, Pfitzner A, Enders G. Molecular characterization of an Enterovirus 71 causing neurological disease in Germany. J Neurovirol 2003; 9: 126-128.

158. Christensen E, Nordbo AG. Enterovirus infections diagnosed in middle Norway during the period 1992-2001. Tidsskr NorLaegeform 2003; 123: 3180-3183.

159. Bernit E, de Lamballerie X, Zandotti C, et al. Prospective investigation of a large outbreak of meningitis due to Echovirus 30 during summer 2000 in Marseilles, France. Medicine (Baltimore). 2004; 83: 245-253. 